Review article

\title{
Functional transformation of Albanian and Serbian settlements in the Presheva
}

\author{
Valley, Serbia
}

\author{
Arsim Ejupi \\ Department of Geography, Faculty of Mathematical and Natural Sciences, University of Prishtina, Mother Theresa Str., 10000, \\ Prishtina, Republic of Kosovo \\ E-mail address: arsim.ejupi@uni-pr.edu
}

\begin{abstract}
The aim of this research was to analyse the functional transformation of settlements in the Presheva Valley and the main factors that have affected on these changes. Among the many factors that determine the trend and the rhythm of functional transformation, we have chosen to analyse the relationship between the functional transformation and the ethnic structure of the region. Presheva Valley is situated in the central part of the Balkan Peninsula, with Morava Valley to the north and Vardar Valley to the south. It has an Albanian population who currently make up around 80 percent of the region's population. It includes 67 settlements inhabited by an Albanian population and 71 settlements inhabited by a Serbian population. The Valley was, and remains, the most underdeveloped region in Serbia and the Balkans: the Albanian-inhabited areas are more than 7 times less developed than the average of Serbia. The first part of the article analyses the functional transformation of the settlements inhabited by Albanians, while the second part depicts a comparison of functional transformation between Albanian and Serbian settlements. The analysis is based on census data from 1971 and 2002. Comparison of statistical data of the population by activity within the 30 year period and mapping of statistical data of population by activity indicates a very slow functional transformation of the settlements in the Presheva Valley.
\end{abstract}

KEY WORDS: settlements, functional, transformation, Albanian, Serbian, Presheva Valley

ARTICLE HISTORY: received 13 March 2017; received in revised form 31 May 2017; accepted 8 June 2017

\section{Introduction}

Spatial systems are developed according to various dimensions, structural and functional domains cannot only be addressed at a large scale but also at smaller (urban or rural) scales (SCHAFFER, 1989). The initial function of rural areas was agriculture, thus the natural conditions are considered to be the key factor where the location of rural settlements are concerned (UNVIN \& NASH, 1992). However, as economic development progressed, socioeconomic factors have played a more important part (CHISHOLM, 1967) sharply changing the morphology, function and spatial structure of rural settlements (ZHU ET AL., 2014).

Apart from population size and morphology, functions of settlements represent another important feature. Heterogeneity of the functional structure of rural and urban areas and the different positions and their roles within the settlement network affect the different levels and direction of their transformation. Settlements as permanent places of concentration of the population and their activities have internal and external functions. Internal functions result from the settlement's functional elements and the relationships between them and through them integrate the external functions with nearby settlements that gravitate towards them or vice versa.

The functional features of settlements represent an important group of factors for the development of the settlement networks. Economic stagnation and backwardness of the Valley is reflected in the concentration of a small number of economic and non-economic functions in the urban centres of Presheva, Bujanoci and Medvegja, which despite 
their lack of functional capacities (industrial, educational, service) still lead the role of functional transformation of settlement in the region.

Data from censuses in Serbia for the period 1961-2002 shows that the Albanian population in the Presheva Valley has steadily increased. It should be noted that the small percentage of Albanians in relation to Serbians in 1961 is because of the emigration of a considerable number of the Albanian population to Turkey, while the decline in the number of Albanians from $78.9 \%$ in
1991 to $72.9 \%$ in 2002 is because of the different census methodology (resident population). The census of 2002 excluded about 23,743 inhabitants, or $20.8 \%$ of the total population, of the Presheva Valley, who lived and worked in other European countries (EJUPI \& RAMADANI, 2016). Albanians made up around $94 \%$ of the overall population of the municipality of Presheva in 2002, classifying it as one of the most homogeneous municipalities in terms of ethnic composition (Table 1).

Table 1. Ethnic structure of the Presheva Valley for the period 1961-2002

\begin{tabular}{|l|c|c|c|c|c|c|c|c|c|c|}
\hline \multirow{2}{*}{ Ethnicity } & \multicolumn{2}{|c|}{1961} & \multicolumn{2}{c|}{1971} & \multicolumn{2}{c|}{1981} & \multicolumn{2}{c|}{1991} & \multicolumn{2}{c|}{2002} \\
\cline { 2 - 12 } & Number & $\%$ & Number & $\%$ & Number & $\%$ & Number & $\%$ & Number & $\%$ \\
\hline Albanian & 39,884 & 44.31 & 65,507 & 53.26 & 72,484 & 61.63 & 80,204 & 67.38 & 81,978 & 72.98 \\
\hline Serbian & 45,229 & 50.21 & 37,619 & 39.86 & 18,486 & 30.41 & 14,268 & 25.66 & 24,134 & 21.38 \\
\hline Roma & - & - & 3,113 & 3.29 & 4,056 & 4.74 & 5,032 & 4.95 & 4,306 & 3.91 \\
\hline Others & 4,933 & 5.48 & 3,395 & 3.59 & 2,830 & 3.22 & 2,045 & 2.1 & 1,791 & 1.73 \\
\hline
\end{tabular}

Source: Population census, Year 1961, Vital, ethnic and migration features, Book no. VI, Belgrade, 1967; Population census, Year 1971, Ethnic features of the population, Results by municipalities, Belgrade, 1974; Population census 1991, Population according to national affiliation; Population census 2002, National or ethnic affiliation of the population, Book no. I, Belgrade, 2003

Out of 138 settlements in the territory, the Albanian population lives in 64 rural types of dwelling and 3 urban settlements which are at the same time the region's municipal administrative centres: Presheva, Bujanoci, and Medvegja while Serbians live in the rest of the settlements. Albanians have an absolute majority in 41 settlements. Besides the municipal centres, there are a number of rural settlements with a multi-ethnic population, with Albanians outnumbering other communities.

During the second half of the $20^{\text {th }}$ century, development of industry, infrastructure, transport and modernization of agriculture resulted in significant changes in rural regions, causing the emergence of new demographic processes, changes in economic activities, land uses, construction, and structure and functions of settlements (EGYED, 2012). This did not happen with the rural settlements of the Presheva Valley which because of economic backwardness still relied predominantly on agricultural functions.

\section{Materials, methods and study area}

A combination of geostatistical and cartographical methods have been used to achieve the scientific aims of this article. Using census data from 1971 and 2002 we saw changes in the structure of the population by activity. Based on these changes we can categorize the functional types of settlements. By considering the complexity of the functional structure of the settlements, which is expressed through the population by sector of activity we can distinguish different functional types of settlements that can be obtained by applying different methodologies. In order to see the changes in the structure of the active population, we have chosen the method of functional classification of settlements. Through this method we can determine nine functional types of settlements: agricultural, industrial-agricultural, agriculturalservice, industrial, industrial-agricultural, industrialservice, service and service-agricultural-industrial (ToŠIĆ, 2012). All these transformations have been illustrated by thematic maps using MapInfo and other GIS techniques.

The Presheva Valley is located in the central part of the Balkan Peninsula, more precisely between the Morava Valley in the north and Vardar Valley in the south. It has a very favourable geographical position because these two valleys constitute the most important natural corridor which connects Europe with South East Europe, the Middle East and Northern Africa (EJuPI \& 
RAMADANI, 2016). The Presheva Valley as a unique natural area belongs to Southern Morava in Serbia.

\section{Results and discussion}

Rural settlements in developing countries and regions are often considered as expressions of subsistence economic systems in which farming and fishing cultures produce no more than their individual families can consume (FELMAN ET AL., 2001). This is also the case with rural settlements of the Presheva Valley. Presheva, Bujanoci and Medvegja, as locations of regional development, represent the centres for the organization of production, service delivery, exchange and consumption of goods and information, on the one hand, and the organization of social economic activities in the surroundings, on the other hand. With these functions they have small capacities for social and geographical transformation of settlements and regions (ISLAMI \& EJUPI, 2015),

Spatial and functional impacts of cities in close proximity are observed through extensive social-economic, functional, demographic and morphological transformation of settlements, made under the influence of urbanization and various developmental activities such as deagrarisation and the depopulation process. Simultaneously with the change of functional capacity, they have transformed the spatial, demographic and morphological structure of other settlements in the region.

By the late 60s, the settlements of the valley were distinguished by a high degree of socioeconomic homogeneity, dominated by agricultural structure. In 1971, 92.2\% of settlements were typically agricultural, with the agricultural population accounting for approximately 90\%. Only three settlements have been of agriculturalindustrial type, two settlements belonged to agricultural-service type and three of them to service-agrarian type settlements: Presheva, Medvegja and Bozhinjevc village in the municipality of Bujanoci. The latter has been at the functional hierarchy and is known as a service-industrial settlement, while Banja e Sijarines was a service type settlement.

Orientation towards non-agricultural functions continues to grow slowly during the period 19712002. During this period the development of several new functions in Presheva, Bujanoci and Medvegja, like industrial, administrative, educational and health functions are expressed through the processes of migration towards municipal centres. The beginning of work within several industrial units in Bujanoci and Presheva enabled a soft employment growth of the labor force in the secondary sector.

This development has changed the functional hierarchy of settlements as it appeared in 2002. The number of typical agricultural settlements decreased from 125 in 1971 to 79 in 2002. Thus, the number of agrarian-industrial settlements increased to 16, from three in 1971; the number of industrial-agrarian settlements increased to 8 from one in 1971; while industrial-service status have gained 18 settlements (Table 2). The reduction of agrarian settlements was made in favour of increasing the number of the population participating in the service sector, from 2 in 1971 to 10 in 2002. Meanwhile, industrial-service statuses have gained Presheva, Medvegja and village Lece in Medvegja.

Changes in the structure of the population by activity showed that the secondary sector showed more development than other sectors during the analyzed period. In the Valley, mobility of the population from the primary sector to other sectors has been slower than in other regions of Serbia.

The slow functional transformation of settlements is due to the lack of interest shown by the Serbian state for the social and economic revitalization of the region. The reason lies in the demographic factors, more precisely in the ethnic structure with a high dominance of Albanians within the population. Even within the region itself, Albanians were always discriminated in the field of economic investment. Thus, in the municipality of Bujanoci with a higher percentage of Serbians within the population, the Serbian state has invested more heavily by opening new industrial facilities and providing new jobs. The economic segregation is evident because the Serbian population was mainly employed in these industrial facilities. This was reflected in the faster transformation of the socioeconomic structure of the Serbian-dominated villages, while the settlements with the majority of the Albanian population are dominated even today by an agrarian structure.

Analysis of the compiled statistical data and thematic maps highlight the dynamic changes during this 30-year period in rural areas located outside the municipal centres. In the municipality of Bujanoci there are the Serbian settlements of Rakoci, Levosoje, Bozhinjevci, while in the municipality of Presheva they are Presheva, Rahovica, Trnava, Norcia, Cakanoci and Bugarina.

Spatial-functional transformation of the settlements in the Presheva Valley was made under the influence of the urban settlements of Presheva, Bujanoci and Medvegja. These centres 
represent the organization of production, service delivery, exchange and consumption of goods and information, on the one hand, and economic organization of the social life of the population in residential surroundings, on the other hand. These are centres with a concentration of different economic functions, therefore, their functional capacity appears to be a factor that promotes and stimulates development of the surrounding settlements.

Spatial and functional impacts of cities in their periphery are observed through socio-economic, functional, morphological and demographic transformation of settlements made under the influence of urbanization and the development of different activities, on the one hand, and the depopulation processes on the other hand. Simultaneous changes of functional capacity stimulate spatial, demographic and morphological changes of other settlements in the region. An important indicator to designate extension of settlements and trends of their functional transformation in the Presheva Valley is change in the structure of the active population by activities.

Table 2. Criteria for functional classification of settlements (Krunić et al., 2009)

\begin{tabular}{|l|l|}
\hline \multicolumn{1}{|c|}{ Functional type of settlement } & \multicolumn{1}{c|}{ Criteria $^{1}$} \\
\hline Agricultural & I $>$ or $=60 \%$ \\
\hline Agricultural-industrial & I $>$ II $>$ III \\
\hline Agricultural-service & I $>$ III $>$ II \\
\hline Industrial & II $>$ or $=60 \%$ \\
\hline Industrial-agricultural & II $>$ I $>$ III \\
\hline Industrial-service & II $>$ III $>$ I \\
\hline Service & III $>$ or $=60 \%$ \\
\hline Service-agricultural & III $>$ I $>$ II \\
\hline Service-industrial & III $>$ II $>$ I \\
\hline
\end{tabular}

I - Agricultural settlements; II - Industrial settlements; III - Service settlements

According to the criteria presented in Table 2 we can see that if a settlement has more than $60 \%$ of the population employed in the primary sector, then it is an agricultural settlement. If in a settlement more than $60 \%$ of the population is employed in the secondary sector, it is categorized as an industrial settlement and if a settlement has more than $60 \%$ of the population engaged in the tertiary sector, it belongs to the service type settlement. For the purposes of our research, we have compared the data on the structure of the active population by activities for the period 1971-2002.

Low rates of improvement of social and economic conditions in the valley are also reflected in the slow functional transformation of its settlements. This is a general conclusion at the regional level. However, analysis of the functional transformation of the settlements in correlation with their ethnic structure within the period 1971-2002 shows that the Albanian settlements in the region have experienced a much slower social, geographical and functional transformation. In 1971 of the 67 Albanian settlements, 63 of them, or 94\%, were agricultural settlements as a result of the dominance of the structure of the active population in extensive agriculture. On the other hand, there is a lack of other functional types of settlements showing that the functional structure of Albanian settlements is not diverse. Out of 67 Albanian settlements only 4 belonged to other functional types. These were Bujanoci which had the status of a serviceindustrial settlement, while Presheva and Medvegja had the status of service-agricultural settlements. Medvegja was a small settlement which acquired the status of a small town in 1921 during the reform of the framework of territories and administration (VASOVIĆ, 1998).

Banja e Sijarines is the only settlement which had the status of service type settlement within the period of review. Thermal and mineral water resources with healing properties offer opportunities for usage. The use of these waters dates back much earlier, but planned usage starts only after 1952, when tourist facilities were opened. This activity has increased in recent decades, guiding the majority of the population to deal with service activities. In Bujanoci, with the exception of health utilities between the two World Wars and 
especially after World War II, several industrial facilities were opened, for instance the collection and processing of tobacco, furniture, meat, bottled water industry, which had diverted a significant number of the active population by primary activity to the secondary and tertiary sector of activity. Presheva and Medvegja, although with service functions, during this period continued to have a large number of people involved in agriculture that gave them service-agricultural status.

Within the 30 year period only 9 Albanian settlements of agrarian type have changed their status (Table 3, Fig. 1). These are Terrnoci, Rahovica, Nesalca, Norca, Terrnava, Oslara, Çukarka, Lerani and Golemidolli. Besides Terrnoci, in the municipality of Bujanoci, which advanced its status from agricultural type in agricultural-service type in the municipality of Presheva only Rahovica had the same development while all the other settlements has advanced by just one functional type. The slightly faster functional transformation of Terrnoci and Rahovica was not the result of enrichment of these new settlements with industrial, administrative and service functions, but was due to the vicinity of these settlements to municipal centres. Intensification of daily migrations in rural-urban interactions and employment of the labor force in the secondary and tertiary sectors of municipal centres has led to a faster change in the structure of the active population by sectors in these settlements.

Table 3. Changes of functional types of Albanian settlements between 1971-2002

\begin{tabular}{|c|c|c|c|c|c|}
\hline \multirow{2}{*}{ Function type of settlement } & \multicolumn{2}{|c|}{1971} & \multicolumn{2}{|c|}{2002} & \multirow{2}{*}{ 1971-2002 } \\
\hline & Number & $\%$ & Number & $\%$ & \\
\hline Agricultural & 63 & 94 & 52 & 77,6 & -9 \\
\hline Agricultural-industrial & - & - & 3 & 4,5 & +3 \\
\hline Agricultural-service & - & - & 4 & 5,9 & +4 \\
\hline Industrial & - & - & - & - & - \\
\hline Industrial-agricultural & - & - & 2 & 3,0 & +3 \\
\hline Industrial-service & - & - & 1 & 1,5 & +1 \\
\hline Service & 1 & 1,5 & 1 & 1,5 & 0 \\
\hline Service-agricultural & 2 & 3,0 & 1 & 1,5 & -1 \\
\hline Service-industrial & 1 & 1,5 & 3 & 4,5 & +2 \\
\hline
\end{tabular}

Source: Population census 1971; Activity, Settlement and municipality results, Federal bureau of statistics, Belgrade, 1974; Population, households and houses census, year 2002; Activity and Sex, Settlement results, Book no. 6, Republic Bureau of Statistics, Belgrade, April 2004

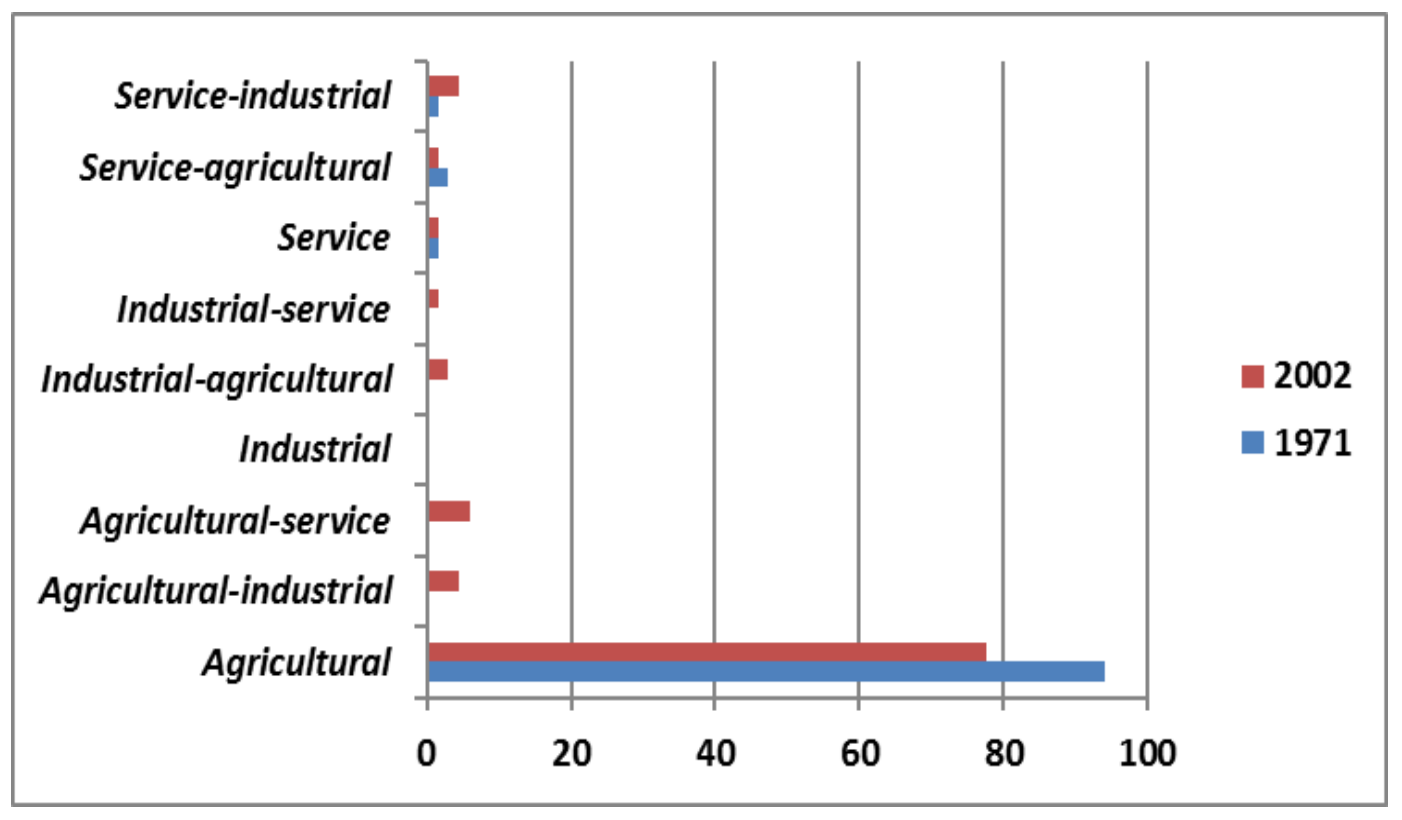

Fig. 1. Changes of functional types of Albanian settlements between 1971-2002 
Table 4. Changes of functional types of Serbian settlements between 1971-2002

\begin{tabular}{|c|c|c|c|c|c|}
\hline \multirow{2}{*}{ Function type of settlement } & \multicolumn{2}{|c|}{1971} & \multicolumn{2}{|c|}{2002} & \multirow{2}{*}{$1971-2002$} \\
\hline & Number & $\%$ & Number & $\%$ & \\
\hline Agricultural & 61 & 88.4 & 28 & 40.6 & -33 \\
\hline Agricultural-industrial & 3 & 4.3 & 12 & 17.5 & +9 \\
\hline Agricultural-service & 2 & 2.9 & 5 & 7.2 & +3 \\
\hline Industrial & - & - & - & - & - \\
\hline Industrial-agricultural & 1 & 1.4 & 6 & 8.7 & +5 \\
\hline Industrial-service & - & - & 16 & 23.2 & +16 \\
\hline Service & 1 & 1.4 & 1 & 1.4 & - \\
\hline Service-agricultural & 1 & 1.4 & - & - & -1 \\
\hline Service-industrial & - & - & 1 & 1.4 & -1 \\
\hline
\end{tabular}

Source: Population census 1971; Activity, Settlement and municipality results, Federal bureau of statistics, Belgrade, 1974; Population, households and houses census, year 2002; Activity and Sex, Settlement results, Book no. 6, Republic Bureau of Statistics, Belgrade, April 2004

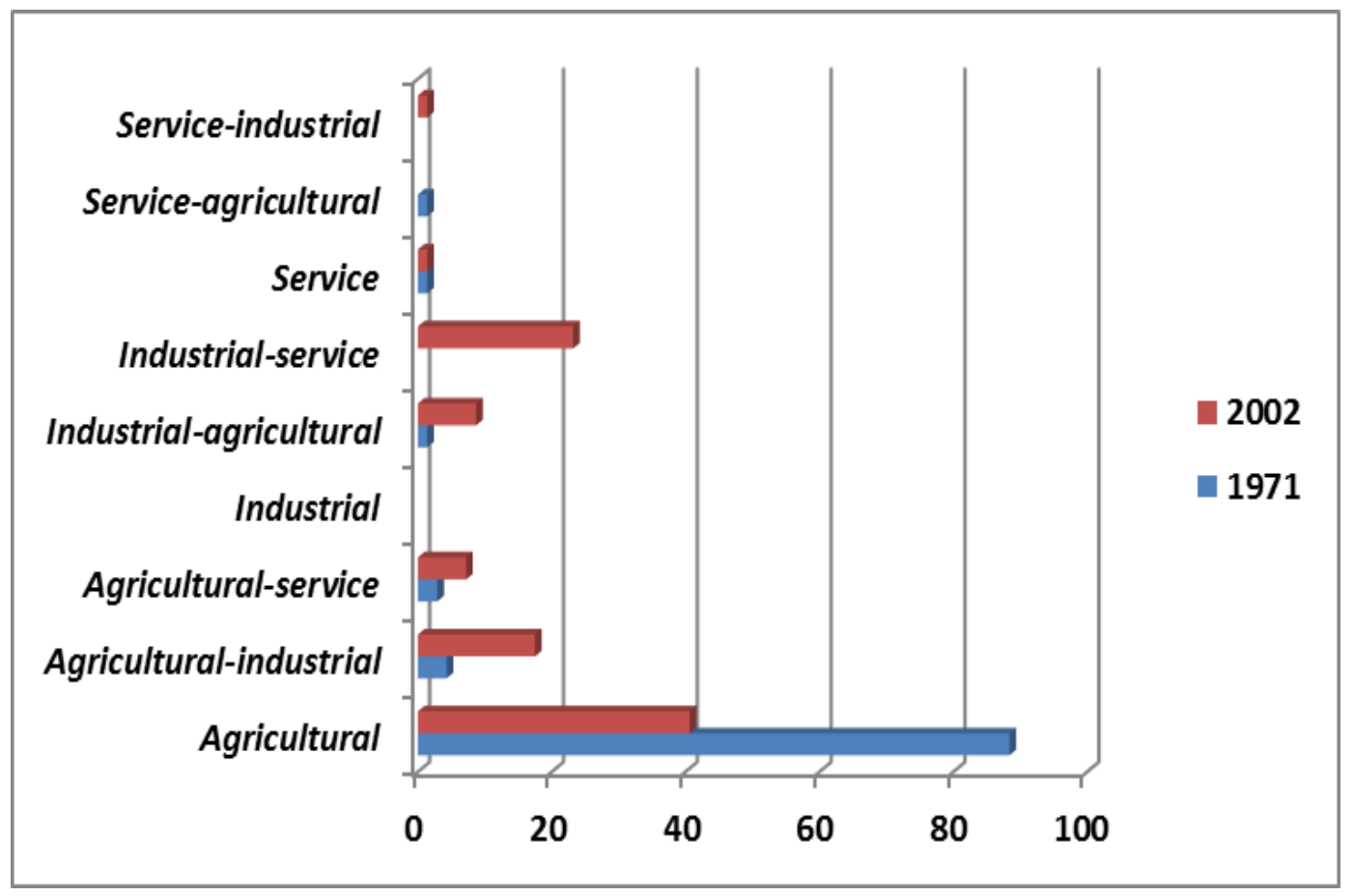

Fig. 2. Changes of functional types of Serbian settlements between 1971-2002

Despite the social and economic backwardness which identified the region in general and in particular its municipalities, there is evidence of intra-regional differences linked to the rhythm of improvement in socio-economic conditions. The Serbian government, never showed an interest for serious investments which would improve the region from backwardness and accelerate the overall socio-economic development despite there being sufficient potential for development which was even larger than in some municipalities and regions. Lack of investment was due to the ethnic and demographical structure of the territory, dominated by the Albanian population. This state policy in the field of investment in the region is a typical example of economic segregation, which had the intention to displace the Albanian population in order to change the ethnic structure of the region. Statistical data analyses and mapping the structure of the active population by sectors in the valley settlements prove the ethnic discrimination in the areas of investment within the region. Settlements with high or a predominant participation of the Serbian population had a rapid functional transformation. In 1971, 61 of the 69 settlements, or $88.4 \%$, were populated by Serbs and belonged 
to the agrarian type, by 2002, this number decreased to only 28 settlements or $40.6 \%$ (Table 4, Fig. 2). Another indicator of the fast rates of functional transformation is functional advancement of settlements for more than one functional category, which was not the case with the Albanian settlements, where most of them advanced by only one category. This proves growing number of industrial-agrarian settlements and industrial-service ones. The number of Serbian settlements of an industrial-agrarian type grew by only $1.4 \%$ as it was in 1971 into $8.7 \%$ in 2001 (Fig. 3). Functional advancement occurred in the largest Serbian settlements of industrialtype service. In 1971, this type of settlement was absent, in 2002 there were 16 such settlements, or $23.2 \%$ of the Serbian settlements belonged to this aforementioned functional category.

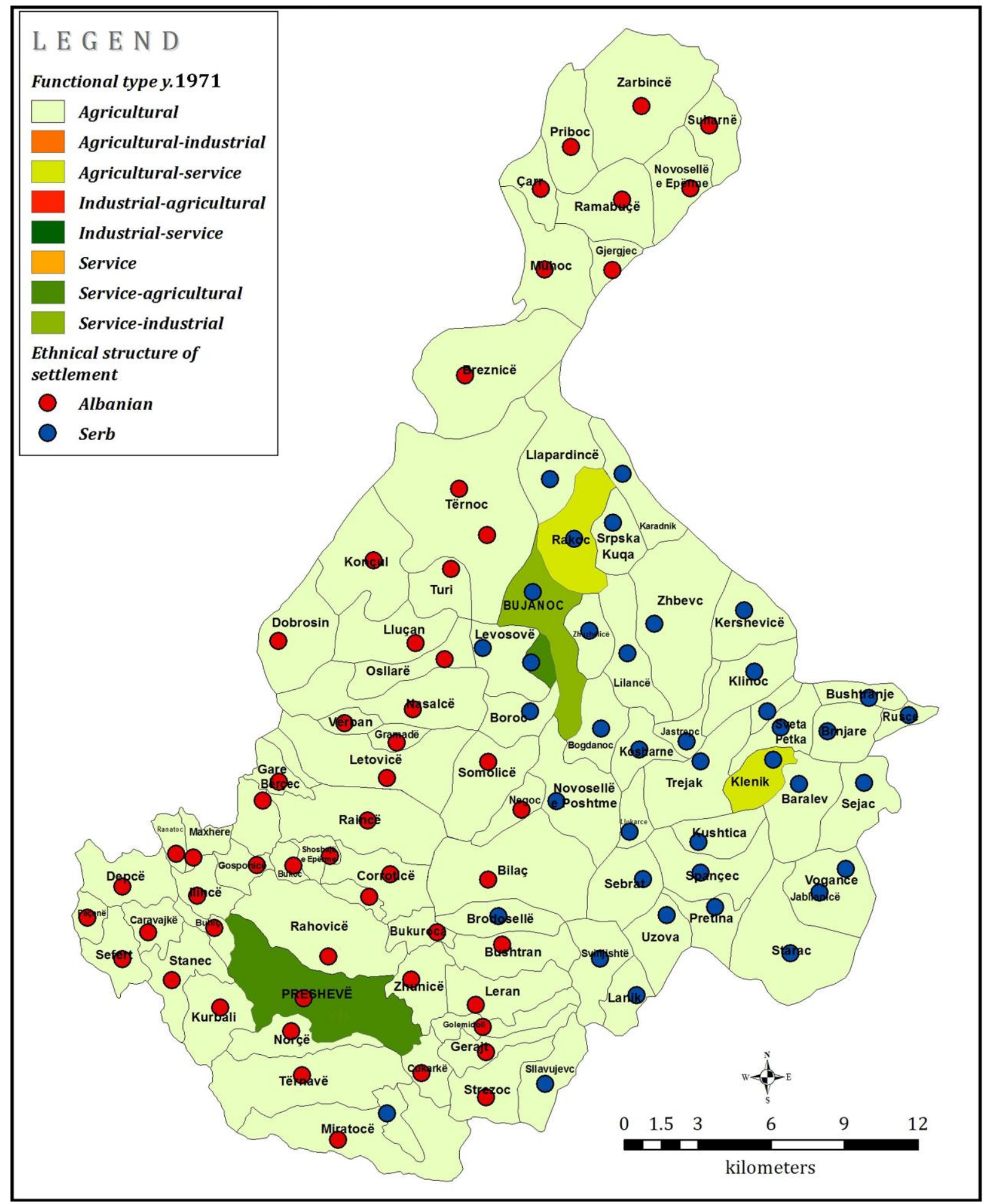

Fig. 3. Functional transformation of settlements in Presheva Valley (in 1971) 
The settlements of Bujanoci with a more diverse ethnic structure and the presence of considerable numbers of ethnically Serb settlements are the best examples of ethnic discrimination in the field of economic development. Besides the municipal centre, functional transformation mostly involves the area gravitating towards Bujanoci, where Serbian villages are concentrated, such as Bozhinjevci, Rakoci, Karadniki, Llopardinca, Levosoje, Zhbevci, Zhuzhelica, as well as settlements along the river valley of Kershevica, such as Kershevica, Sveta Petka, Klinovci and Klenike (Fig. 4). Functional transformation of Serbian settlements entailed well executed policy and strategy by the opening of small industrial facilities mainly in the eastern part of the area gravitating towards Bujanoci and ethnic discrimination in employment, by always giving priority to the Serb population in the few industrial enterprises and other service activities in the town of Bujanoci.

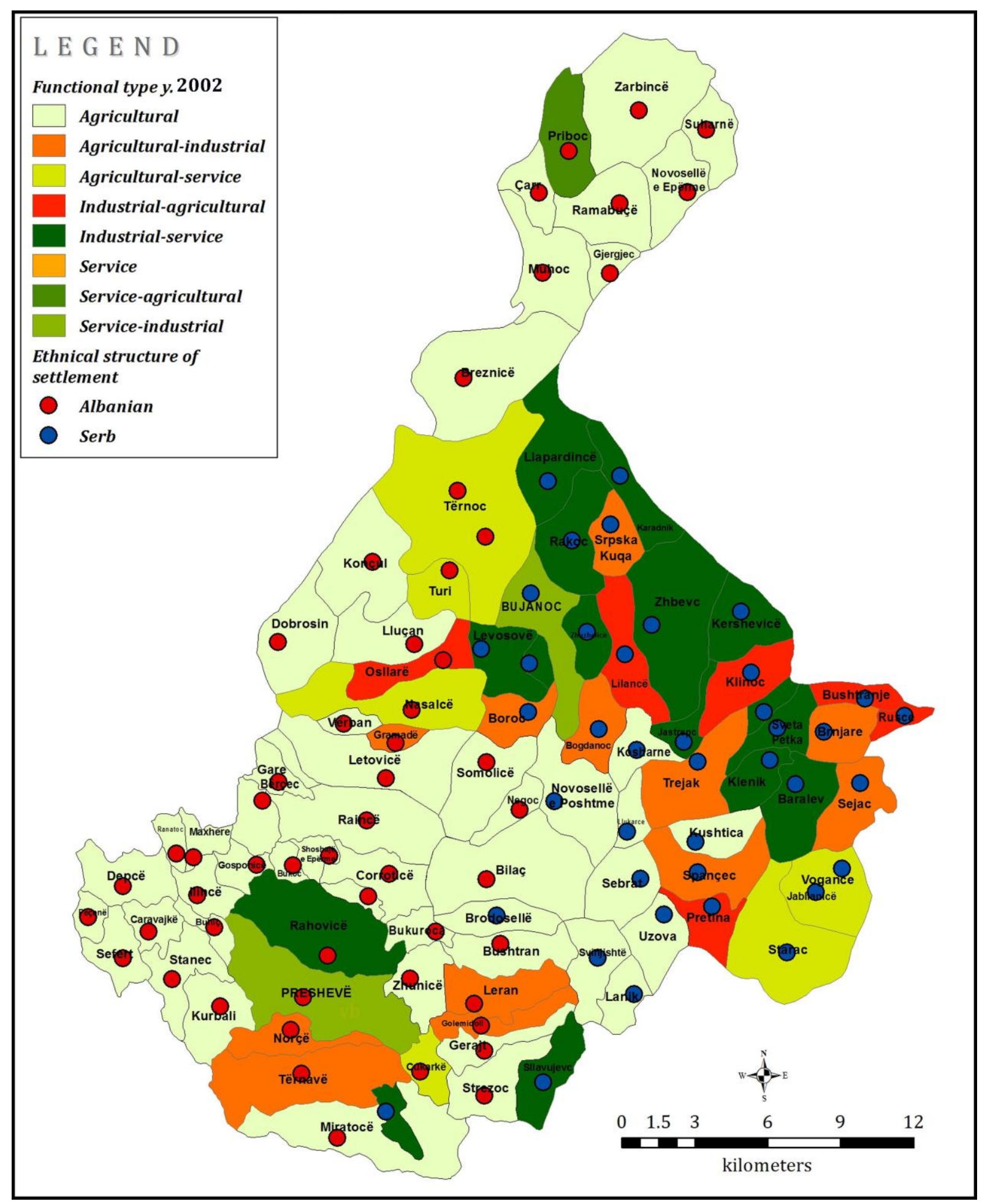

Fig. 4. Functional transformation of settlements in Presheva Valley (in 2002) 


\section{Conclusion}

Functional transformation of the settlements of the region has been slow, mostly due to the employment of the population in non-agricultural occupations, and less from distribution of functions, industrial buildings, and public and social infrastructure in rural areas of the region. This transformation has taken place within a poorly developed road network and insufficient infrastructure, which has reduced access of rural settlements in mountainous areas in the municipalities of Presheva and Bujanoci and their connections. This development has consequences by development of dichotomy migration process: emigration and depopulation of villages, while in larger settlements especially the municipalities of Presheva and Bujanoci comes to the growth of urban settlements gravitating area nearby. This inevitably leads to polarization of the population, where the municipal centres and their peripheries are faced by demographic growth, while settlements of hilly-mountainous areas have experienced the depopulation processes.

To prevent the continuation of these processes within the region we believe that the current system of spatial-functional organization should be changed, especially in hilly and mountainous areas, by raising some settlements within the spatial-functional hierarchy. Functional development of some rural centres in these areas in the future will decrease the rhythm of the depopulation processes and help the rational and efficient organization of economic activities within the network of settlements, development of rural tourism and ecotourism, farming, collecting and processing of wild fruits. Construction and improvement of road infrastructure will help in the overall revitalization of these areas.

\section{References}

Chisholm M. 1967. Rural Settlement and Land Use. John Wiley \&
Sons, New York, USA.

Egyed A. 2012. Landscape transformation in rural areas, connection between the changes of the function and the character of the small villages on the example of three micro-region. Dissertation Bookle, Corvinus University of Budapest, Budapest.

Ejupi A. 2013. Presheva Valley - comprehensive geospatial study. Kosovar Academy of Sciences and Arts, Prishtina.

Ejupi A., Ramadani I. 2016. Regional differentiation and the geopolitical and transboundary position of the Presheva Valley. Miscellanea Geographica - Regional studies on development, 20, 4: 22-28.

Felman J., Getis A., Getis, J. 2001. Human Geography. McGraw and Hill.

Islami H., Ejupi A. 2015. Albanian population and settlements of Presheva Valle. Kosovar Academy of Sciences and Arts, Prishtina.

Krunić N., Tošić D., Milijić S. 2009. Problems of spatial functional organization of Južno Pomoravlje region network of settlements. SPATIUM, Belgrade, 19: 23-29.

Shaffer F. 1989. About the concept of social geography. Geogr. Educ. Growth, 18: 7-14.

Tošić D. 2012. Principles of regionalization. Faculty of Geography, University of Belgrade, Belgrade.

Unvin T., Nash B. 1992. Township boundaries: theoretical considerations and analytical implications. In: The transformation of the European rural landscape: Methodological issues and agrarian change 1770-1914, Verhoeve, A., Vervloet J.A. (eds.), 61, Belgische Vereniging voor Aardrijkskundige Studies, Tehran, Iran, 8: 116-127.

Vasović M. 1998. Gornja Jablanica - geografska svojstva. Beograd.

Zhu F., Zhang C. Li, Zhu T. 2014. Functional transition of the rural settlement: Analysis of land-use differentiation in a transect of Beijing, China. Habitat International, 41: 262-271.

\section{Sources}

Population Census 1971, Activity, Settlements and municipality results, Federal bureau of statistics, Belgrade: 315-323.

Population Census 2002, Activity and sex, Settlement results, Book nr. 6, Republic bureau of statistics, Belgrade: 548-588.

Population census 1961, Vital, ethnical and migration features, Book number VI, Belgrade, 1967.

Population census 1971, Ethnical features of population, Results by municipalities, Belgrade, 1974.

Population census 1991, Population according to national affiliation.

Population census 2002, National or ethnical affiliation of population, Book number I, Belgrade, 2003. 